\title{
High-resolution modeling of tsunami run-up flooding: a case study of flooding in Kamaishi city, Japan, induced by the 2011 Tohoku
} tsunami

\author{
Ryosuke Akoh $^{1}$, Tadaharu Ishikawa ${ }^{2, *}$, Takashi Kojima ${ }^{3}$, Mahito Tomaru ${ }^{3}$, and Shiro Maeno ${ }^{1}$ \\ ${ }^{1}$ Graduate School of Environmental and Life Science, Okayama University, Okayama, 700-8530, Japan \\ ${ }^{2}$ Tokyo Institute of Technology, Kanagawa, 226-8503, Japan \\ ${ }^{3}$ TOKEN C. E. E. Consultants Co., Ltd., Tokyo, 174-0004, Japan \\ *retired
}

Correspondence to: Ryosuke Akoh (akoh@okayama-u.ac.jp)

Received: 20 June 2017 - Discussion started: 4 July 2017

Accepted: 13 September 2017 - Published: 6 November 2017

\begin{abstract}
Run-up processes of the 2011 Tohoku tsunami into the city of Kamaishi, Japan, were simulated numerically using 2-D shallow water equations with a new treatment of building footprints. The model imposes an internal hydraulic condition of permeable and impermeable walls at the building footprint outline on unstructured triangular meshes. Digital data of the building footprint approximated by polygons were overlaid on a $1.0 \mathrm{~m}$ resolution terrain model. The hydraulic boundary conditions were ascertained using conventional tsunami propagation calculation from the seismic center to nearshore areas. Run-up flow calculations were conducted under the same hydraulic conditions for several cases having different building permeabilities.

Comparison of computation results with field data suggests that the case with a small amount of wall permeability gives better agreement than the case with impermeable condition. Spatial mapping of an indicator for run-up flow intensity $\left(I_{\mathrm{F}}=\left(h U^{2}\right)_{\max }\right.$, where $h$ and $U$ respectively denote the inundation depth and flow velocity during the flood, shows fairly good correlation with the distribution of houses destroyed by flooding. As a possible mitigation measure, the influence of the buildings on the flow was assessed using a numerical experiment for solid buildings arrayed alternately in two lines along the coast. Results show that the buildings can prevent seawater from flowing straight to the city center while maintaining access to the sea.
\end{abstract}

\section{Introduction}

Recent urbanization of low-lying coastal areas has increased the potential for property damage, human injury, and death caused by tsunamis. Visual data obtained during the tsunami run-up have revealed that arrays of structures in urban areas induced large wave deformation and swift currents on streets, and that the currents washed objects such as garbage, cars, and debris from damaged structures, causing even more damage than the tsunami run-up over uniform ground. Prediction of swift currents in urban areas by numerical flow simulation is expected to be important for evacuation programs and for city layout planning measures to mitigate tsunami damage.

Tsunami simulation models for forecasting wave propagation and deformation from the seismic center to the coast have been developed and improved for decades. These models for high-speed calculations in a wide water body are often based on a set of shallow water equations on a structured rectangular grid system (Imamura et al., 1995). Models with a rectangular grid system were extended to calculate the tsunami run-up on land by formulating the wavefront propagation on a dry bed (Titov and Synolakis, 1995, 1998; Synolakis et al., 2008). However, the tsunami run-up simulation described above requires more precise flow modeling by introduction of the hydraulic effects of building arrangement.

Building array treatments in urban flood inundation models are classifiable into four types (Schubert et al., 2008, 2012): building-resistance models (BR), in which large surface roughness is assigned to cells that fall within a building 
(a)

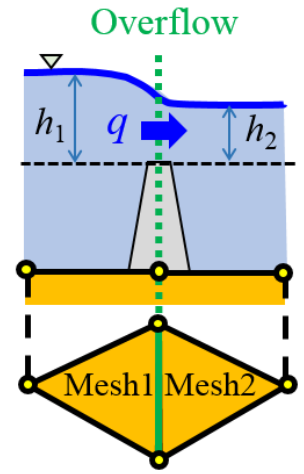

(b)

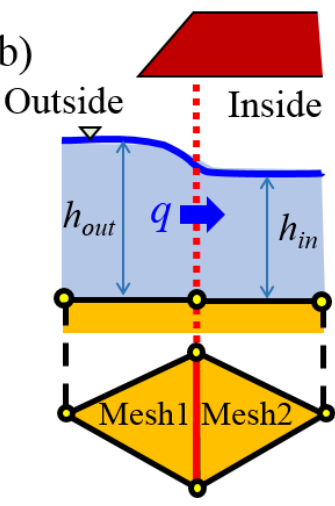

in the earlier study. Sect. 2 describes the numerical simulation method: basic formulations and building array treatment. Sect. 3 is devoted to an explanation of numerical modeling for the tsunami flooding in Kamaishi city: explanation of the study site, data sources for modeling, mesh generation, and calculation conditions. Calculation results are displayed in Sect. 4 along with validation data. In Sect. 5, after presenting discussion of the influence of the permeability constant on calculation results, the tsunami effects on houses were examined. We introduce an indicator, $I_{\mathrm{F}}=\left(h U^{2}\right)_{\max }$, where $h$ and $U$ respectively denote the water depth and the flow velocity at each point. In addition, we numerically tested effects of rigid building arrays along the coast on the reduction of $I_{\mathrm{F}}$ in the city center as a possible mitigation measure to be used instead of high continuous embankments, which prevent access to the sea.

\section{Methods}

Considering the openings of wooden houses such as doors, windows, or cracks and slits caused by tsunami effects, the shallow water BH model was improved to express the effects of wall permeability by introducing the "assumption of internal hydraulic conditions" on line segments where the walls were located. The seawall overtopping was considered similarly.

\subsection{Numerical model}

Two-dimensional shallow water equations were adopted for numerical simulations: a continuity equation for an incompressible fluid and momentum equations used under the assumption of hydrostatic pressure without horizontal diffusion terms in Cartesian coordinates. The Godunov-type finite volume method (Godunov et al., 1959) was used to solve the hyperbolic differential equations. The spatial domain of integration was covered by a set of unstructured triangular cells, which are not necessarily aligned with the coordinates. Therefore, the topography and building footprints were expressed flexibly. The cell-averaged values for water depth, velocity components, and ground surface elevation were assigned at the centroid of each triangle.

By integrating the equation over each triangular cell and by application of Gauss's theorem to the flux integral, a finite-differential equation for time evolution of variables was obtained. The method of characteristics was applied to the flux terms. Roe's approximate Riemann solver (Roe, 1981) was adopted, based on the first-order upwind approach. In the finite differentiation of the momentum source term induced by ground slope, an upwind approach was also adopted to satisfy the $C$-property condition for avoiding nonphysical oscillations by ensuring the balance with the flux term in the steady condition (Zhou et al., 2001). The momentum source term induced by bed friction, which was ex- 


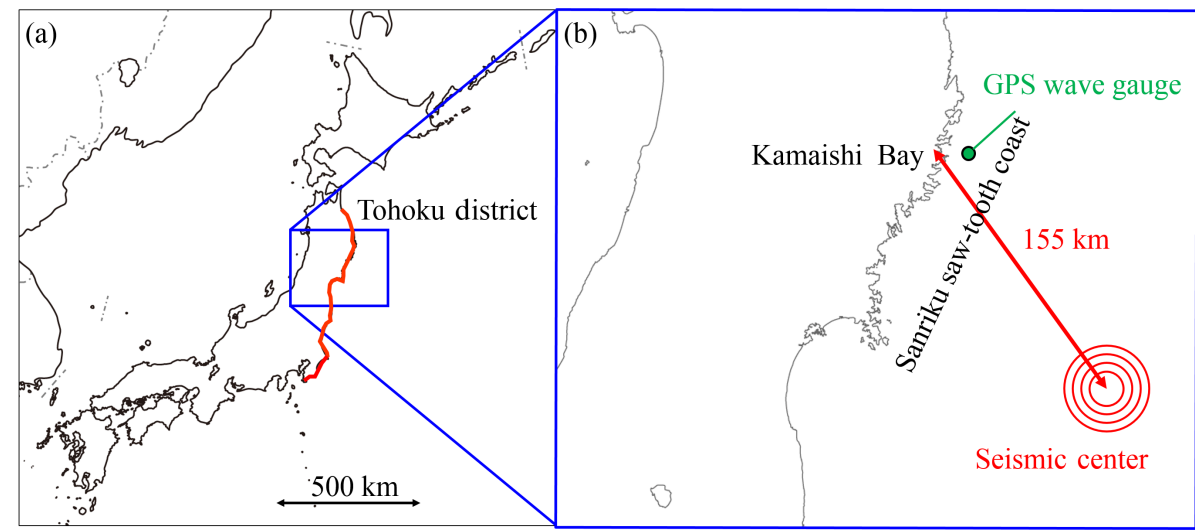

Figure 2. Geometry of coastlines and location of the study site. (a) Map of Japan. Red shows the coastal region damaged by the 2011 Tohoku tsunami. (b) Locations of the seismic center, Kamaishi Bay, and the nearest GPS wave gauge.

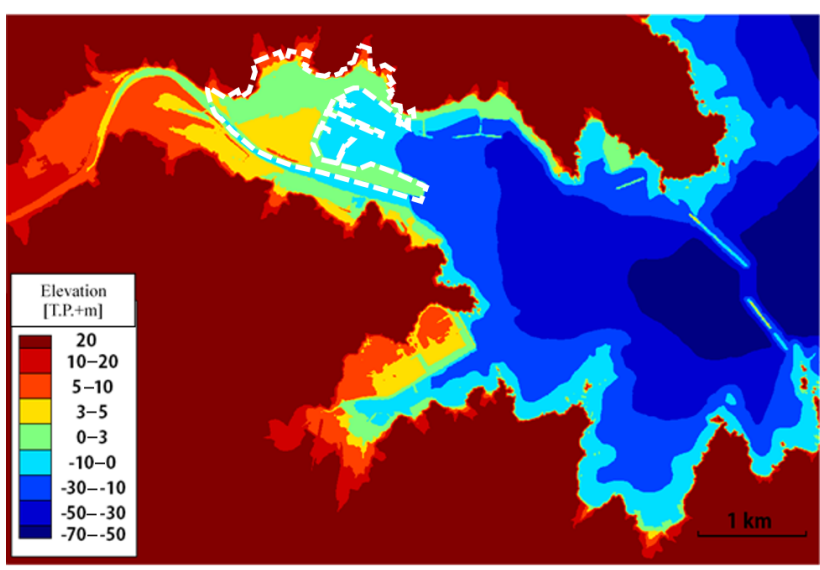

Figure 3. Bathymetry and surrounding topography of Kamaishi Bay. Tokyo Peil (T.P.) + m: elevation above the average sea level in Tokyo Bay.

pressed by Manning's roughness, was given by the spatial average.

To model wavefront motion, the Eulerian method proposed by Brufau (2002) was adopted to avoid the so-called $C$-property collapse at the border between a wet cell and a dry bed cell. This method temporarily sets the ground elevation of the dry bed cells adjacent to the wet area as equal to the water surface level in the neighboring wet cell. A more detailed description of the method was presented in an earlier report (Akoh, 2014).

\subsection{Assumptions of internal boundary conditions}

Effects of seawalls on a flood flow are expressed by imposing the following internal hydraulic conditions on line segments where the seawalls are located.

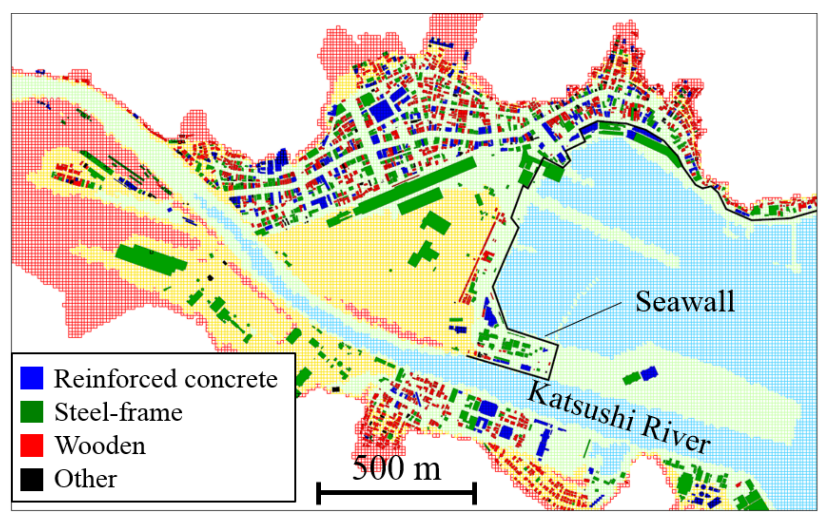

Figure 4. Classification of building structures.

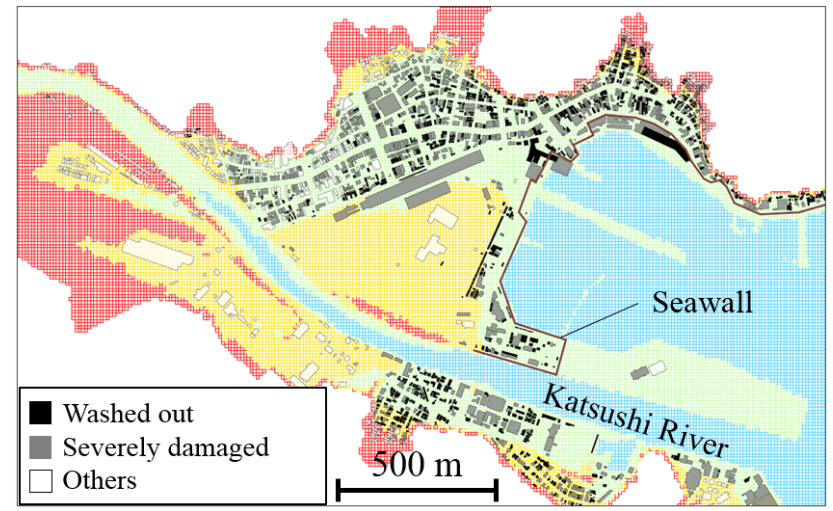

Figure 5. Classification of building damage.

$q= \begin{cases}0.35 h_{1} \sqrt{2 g h_{1}} & \text { if } h_{2} / h_{1}<2 / 3 \\ 0.91 h_{2} \sqrt{2 g\left(h_{1}-h_{2}\right)} & \text { otherwise }\end{cases}$

For those expressions, $q$ is the volumetric flow rate over a unit length of seawall. In addition, $h_{1}$ and $h_{2}$ respectively 


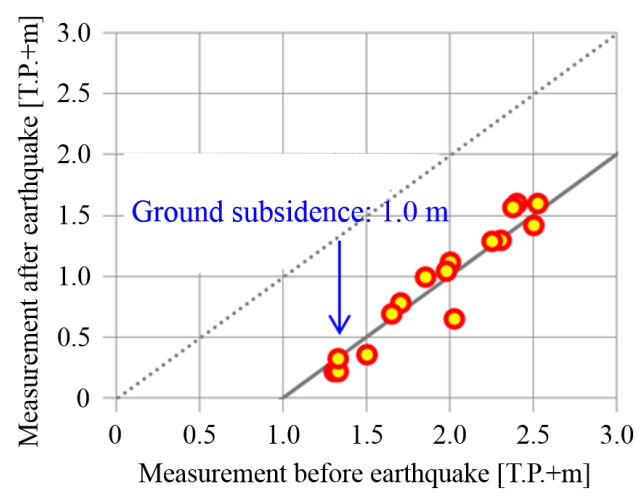

Figure 6. Ground subsidence near the coast. (a)

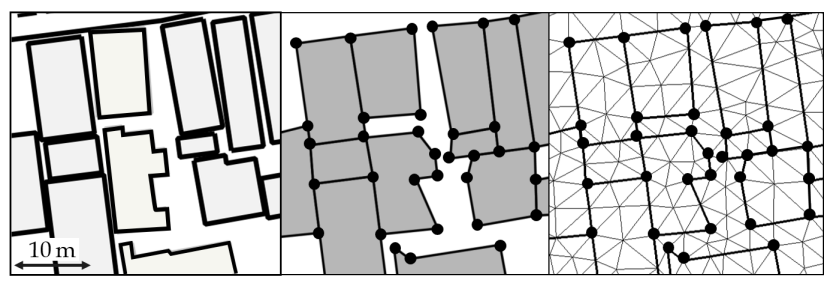

Figure 7. Simplification and redefinition of building footprint polygons.

denote the water depths above the crown at the upstream and downstream sides (see Fig. 1a). The first equation and the second equation respectively represent free overflow and submerged overflow (Honma, 1940).

Ordinary BH models exclude building footprints from the calculation area using a free-slip interior boundary condition. In this study, effects of buildings on a flood flow are expressed by imposing the following internal hydraulic condition on the line segments of building footprint outlines.

$q= \pm C \sqrt{2 g\left|h_{\mathrm{out}}-h_{\mathrm{in}}\right|}\left(h_{\mathrm{out}}+h_{\mathrm{in}}\right) / 2$

Therein, $q$ denotes the flow rate across a unit length of the wall; $h_{\text {out }}$ and $h_{\text {in }}$ respectively represent the water depths immediately outside and inside the wall; $\left(h_{\text {out }}+h_{\text {in }}\right) / 2$ denotes the average wetted height of the wall; $\left(h_{\text {out }}-h_{\text {in }}\right)$ represents the water surface difference across the wall (see Fig. 1b); $g$ stands for gravitational acceleration; and $C$ is a constant representing the wall permeability resulting from openings such as doors, windows, or cracks and slits caused by wave impacts. Positive and negative signs respectively denote cases in which $h_{\text {out }}>h_{\text {in }}$ and $h_{\text {out }}<h_{\text {in }}$. In an impermeable condition $(C=0)$, the model is equivalent to the $\mathrm{BH}$ model.

\section{Application: inundation in Kamaishi city from the 2011 Tohoku tsunami}

The 2011 earthquake off the Pacific coast of Tohoku, with $M_{\mathrm{w}} 9.0$ seismic magnitude, hit the northeastern Pacific coast of Japan on 11 Mar 2011. The total death toll including missing persons reached about $18000,90 \%$ of whom were killed by the tsunami which struck soon after the earthquake in lowlying urban areas on the coast. Kamaishi city was one of the severely damaged municipalities.

\subsection{Site description}

Kamaishi city is located at the inner part of the Kamaishi Bay in the southern Sanriku sawtooth coast of Tohoku district, Japan (Fig. 2). The distance between the bay mouth and the seismic center of the 2011 Tohoku earthquake is only $115 \mathrm{~km}$. A GPS wave gauge placed $20 \mathrm{~km}$ offshore from the bay mouth recorded the time series of the water surface displacement induced by the 2011 Tohoku tsunami.

Figure 3 presents the bathymetry and surrounding topography of Kamaishi Bay, where Tokyo Peil (T.P.) + m denotes the elevation in meters above the average sea level in Tokyo Bay, which is the standard elevation unit in Japan. A breakwater to prevent tsunami wave intrusion was built at the bay mouth in 2009 after several tsunami disasters occurred in the 19th and 20th centuries. Nevertheless, the upper part of the structure was destroyed by the first wave of the 2011 Tohoku tsunami. The center of Kamaishi city is located on narrow lowland surrounded by mountains inside the bay. The Kamaishi city population of approximately 35000 is mainly reliant on marine product industries and the steel industry.

Figure 4 depicts the building distribution in the city center before the earthquake provided by Geospatial Information Authority of Japan (GSI), where the colors show materials used in the construction of individual buildings. Approximately 2500 small buildings were clustered close together in a narrow area. More than half of these buildings were mortared wooden houses (shown as red). The old coastline was at the southern margin of this dense building cluster. The open space between the old coastline and the present coastline is reclaimed land used as a fishing port, a market, and a loading yard. Most of the steel-frame buildings (shown as yellow) were workshops and storehouses used for marine industries. Concrete panels covered the side faces of these buildings. The black line along the coast represents a concrete seawall, the crown elevation of which was T.P. $+4 \mathrm{~m}$.

The height of the first wave of the 2011 Tohoku tsunami was approximately $10 \mathrm{~m}$ at the coast near the city center. A large volume of seawater overtopped the seawall and struck the buildings. Black cells in Fig. 5 show the buildings that had been destroyed completely (washed away) by the tsunami waves. Gray cells show remaining buildings that were nonetheless severely damaged (GSI). Most buildings in the city were damaged severely, among which the destroyed 


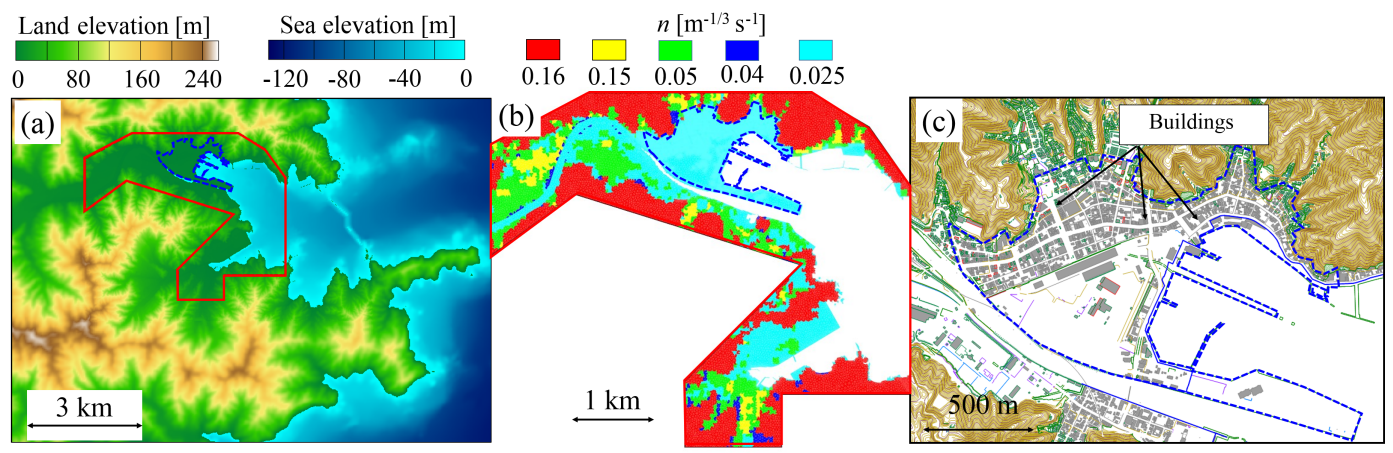

Figure 8. Area of calculation domain: (a) geometry of calculation domain in a wide view, (b) Manning's roughness in calculation domain corresponding to the red line in (a), and (c) domain for detailed calculation corresponding to the blue dotted line in (a).

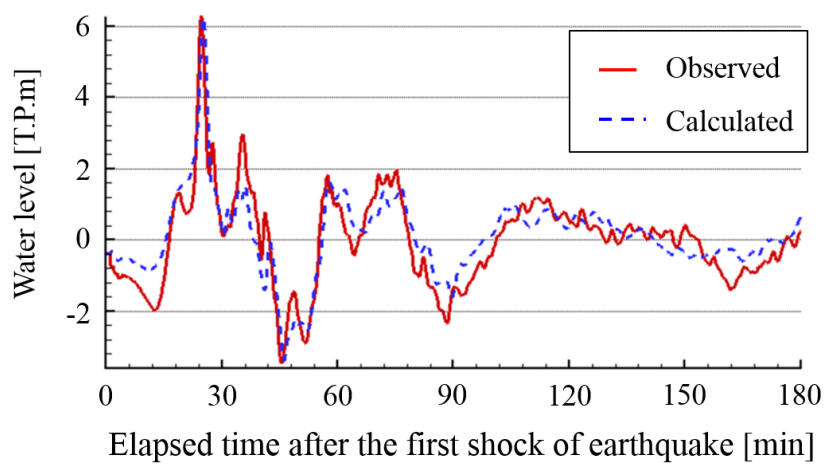

Figure 9. Water surface displacement at the GPS wave gauge station.

buildings were mortared wooden houses, which are common throughout Japan.

\subsection{Model setup}

\subsubsection{Topographical conditions}

Based on GPS elevation monitoring by GSI, large ground displacement occurred within a short time immediately after the first shock of the earthquake. The movement ceased before the first tsunami wave's arrival at Kamaishi Bay (GSI). Figure 6 shows ground elevation data obtained near the coastline of Kamaishi Bay before and after the earthquake, which indicate approximately uniform subsidence of $1 \mathrm{~m}$.

Therefore, the ground elevation data for the numerical flow simulation were referred from a $1.0 \mathrm{~m}$ resolution digital elevation model provided by GSI based on aerial laser scanning after the earthquake. No bathymetry measurements were available for Kamaishi Bay after the earthquake at the time of the present study. Therefore, the seafloor elevation was estimated by subtracting $1 \mathrm{~m}$ from measurements taken before the earthquake (Japan Oceanographic Data Center). As described earlier, the upper part of breakwater at the bay mouth was destroyed by the first wave of the 2011 Tohoku tsunami. Tomita et al. (2012) investigated the effect of breakwater on the tsunami propagation into the bay by comparing three calculations: with the breakwater before tsunami arrival, with damaged breakwater configuration measured after the tsunami, and without breakwater, whereas the actual process of breakwater destruction remains as a subject for future study. Therefore, in this study, the damaged configuration measured after the tsunami (Takahashi et al., 2011) was assumed for calculation.

\subsubsection{Seawalls and building footprints}

GSI (2011) provided by GSI includes a dataset of structure plane figures before the earthquake. The seawall positions were approximated by line segments using GIS software SIS

The digital base map also includes building footprint outlines as corner positions of polygon geometry. However, overly fine expression of irregular building shapes and tight spacing are expected to degrade the computational efficiency. For that reason, building footprints were simplified: polygon sides shorter than $2.5 \mathrm{~m}$ were eliminated by erasing some corners. Building gaps narrower than $1.5 \mathrm{~m}$ were avoided by aggregating polygons. An example of simplification is portrayed in Fig. 7. About 2742 buildings were found in the digital base map for detailed calculations in the city center area. The number was reduced to about 1800 after polygon aggregation.

\subsubsection{Mesh generation}

The red line in Fig. 8a presents the total area for tsunami run-up simulation. The blue dotted line shows the area of detailed calculations in which building footprints were quantified. Figure $8 \mathrm{~b}$ and $\mathrm{c}$ portray enlarged images of the two areas. For areas with detailed calculation, a triangular mesh system was constructed from the position dataset of seawalls and building corners using software (ANSYS ${ }^{\circledR}$ ICEM $\mathrm{CFD}^{\mathrm{TM}}$ ), under a minimum angle constraint of $30^{\circ}$ to avoid computational instability caused by acute angles. The ground elevation at each triangle centroid was obtained by interpo- 
(a)

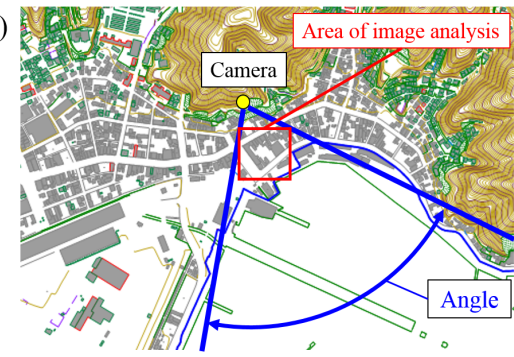

(b)

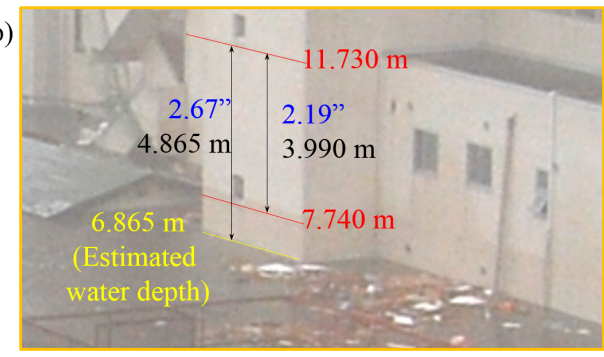

Figure 10. Estimation of tsunami wave height near the coast: (a) shooting area and (b) illustration of analysis.

(a)

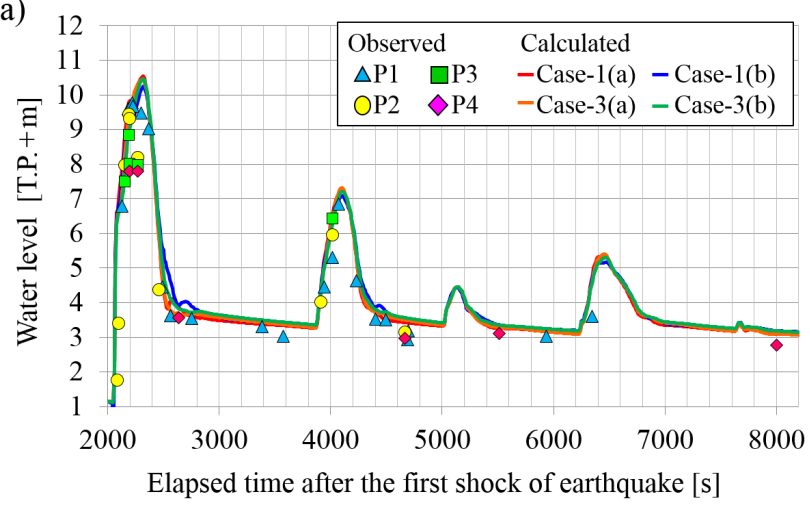

(b)

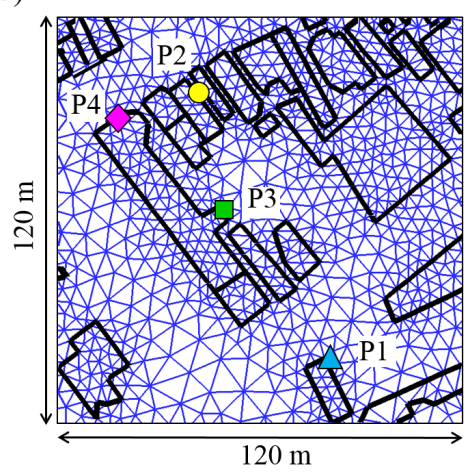

Figure 11. Time series of water surface displacement near the coast: comparison between (a) measured and (b) calculated target points for photograph analysis.

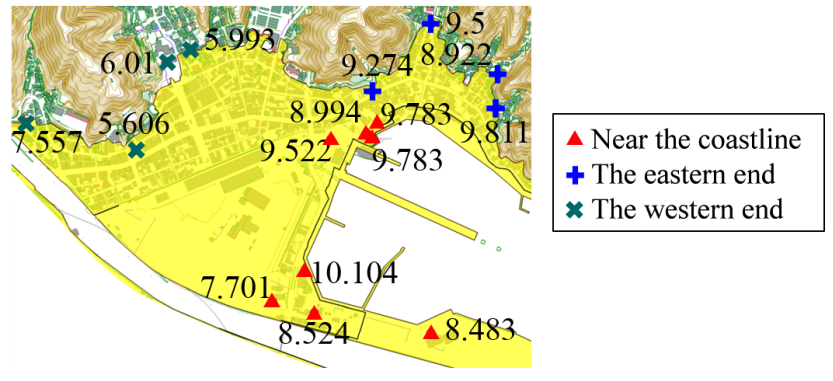

Figure 12. Data of water surface traces (TTJS Group, 2011): plots show positions of measurements; numbers show the measured height in T.P. $+\mathrm{m} ; \boldsymbol{\Delta},+$, and $\times$ show measurement locations; the numbers are maximum water levels.

lating the $1.0 \mathrm{~m}$ resolution digital model provided by GSI. Manning's roughness coefficient was assumed as $n=0.02$ because almost all land surfaces in the detailed calculation area were roads and bare ground (except for building footprints).

For the areas of suburbs and water (outside the blue dotted line), triangular mesh systems were constructed using ANSYS ${ }^{\circledR}$ ICEM CFD ${ }^{\mathrm{TM}}$ based on the coast locations, bed elevation contour lines, and land-use classification boundaries. Manning's roughness coefficient was assigned as described
Table 1. Manning's roughness coefficients.

\begin{tabular}{lr}
\hline Land use & $\begin{array}{r}\text { Manning's } \\
\text { roughness }\left(\mathrm{s} \mathrm{m}^{-1 / 3}\right)\end{array}$ \\
\hline Water area & 0.025 \\
Farmland & 0.04 \\
Forest & 0.16 \\
Factory site & 0.05 \\
Residential area (low density) & 0.05 \\
Residential area (high density) & 0.15 \\
Road, vacant land & 0.025 \\
\hline
\end{tabular}

by Bunya (2010) and Bricker et al. (2015) for each land-use classification, as presented in Table 1 and as shown with colors in Fig. 8b. In all, 146665 computation grid areas were created for the whole calculation area.

\subsection{Hydraulic condition for calculation}

The hydraulic conditions at the east open boundary of calculation area were given by the conventional tsunami propagation model in the ocean (TUNAMI-N2, Imamura, 1996) with rectangular grids. For calculation efficiency, a sevenstep, one-way nesting method was adopted with grid sizes of 3240 to $10 \mathrm{~m}$. The time increment of computation was as- 
(a)

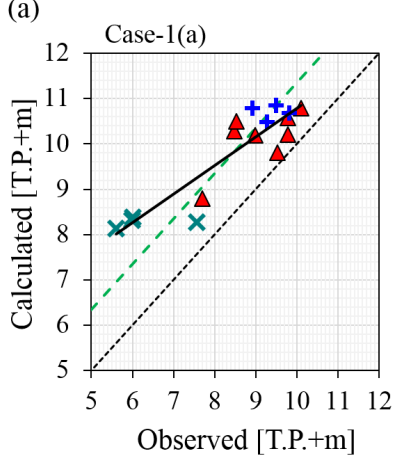

(c)

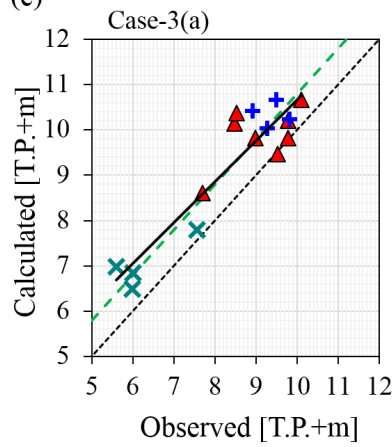

(b)

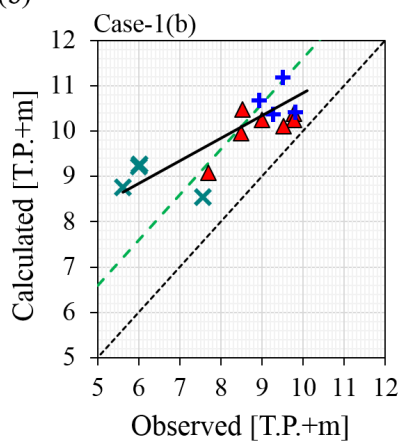

(d)

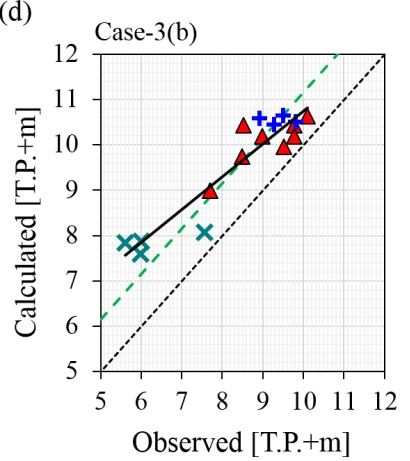

Figure 13. Comparison between calculated and measured maximum heights. Symbols are the same as those used for Fig. 12: (a) Case-1(a) $-C=0.0$, buildings before tsunami; (b) Case-1(b) $-C=0.0$, buildings after tsunami; (c) Case-3(a) $-C=0.01$, buildings before tsunami; and (d) Case-3(b) $-C=0.01$, buildings after tsunami.

Table 2. Numerical simulation cases.

\begin{tabular}{lcc}
\hline \multirow{2}{*}{$\begin{array}{l}\text { Permeability } \\
\text { constant, } C\end{array}$} & \multicolumn{2}{c}{ Building layout } \\
& before tsunami & after tsunami \\
\hline 0.0 & Case-1(a) & Case-1(b) \\
$10^{-3}$ & Case-2(a) & Case-2(b) \\
$10^{-2}$ & Case-3(a) & Case-3(b) \\
$10^{-1}$ & Case-4(a) & Case-4(b) \\
$10^{0}$ & Case-5(a) & Case-5(b) \\
\hline
\end{tabular}

certained from the criterion of the CFL (Courant-FriedrichsLewy) condition for each nesting process. The initial distribution of the water surface setup was obtained from the estimation presented by the Central Disaster Prevention Council (2012). The calculation results were compared with data obtained using a GPS water gauge located $20 \mathrm{~km}$ off the mouth of Kamaishi Bay (see Fig. 1). Figure 9 shows calculated and measured results for the sea surface displacement at a GPS wave gauge station. The agreement was sufficient. The calculated time series of water surface elevation and momentum flux at the east open boundary were imposed on the tsunami run-up model described in earlier chapters.

Numerical simulations were conducted with time increment $\Delta t=0.025 \mathrm{~s}$ for the cases presented in Table 2 . In Case-1(a), building walls were assumed to be impermeable $(C=0)$ for building arrays in the city center area before the tsunami run-up, but, in Case-1(b), $C=0$ for building arrays without houses destroyed by tsunami flooding. Case2(a)-Case-5(a) and Case-2(b)-Case-5(b) were counterparts of Case-1(a) and Case-1(b), in which $C$ was changed respectively as $10^{-3}, 10^{-2}, 10^{-1}$, and $10^{0}$.

\section{Validation of results}

Data of many kinds were collected by academic groups, governments, and municipalities after the earthquake. The results obtained from the numerical simulation described in the previous chapter are presented herein and are compared to those real data.

\subsection{Tsunami wave height near the coast}

\subsubsection{Field data analysis}

As described earlier, the breakwater at the bay mouth was considered with damaged configuration measured after the tsunami because of the uncertainty of its destruction process. In this study, therefore, time series of tsunami wave height near the coast line were obtained using image analysis of digital photographs taken by residents. Using them, we examined the calculated time series near the coast line for use in run-up calculations in the city center area. Figure 10a portrays the shooting point and the view angle, shown respectively by the yellow dot and the blue lines, in an area (shown as red) where some concrete buildings withstood the tsunami. The water surface elevation at each time was estimated by comparison with the window height, as measured by the authors after the area was made accessible for tsunami damage investigations. Figure 10b presents an example in which the red numbers denote heights from the ground of the lower window frames. Blue numbers and black numbers respectively denote the vertical angle differences and the elevation differences of the lower window frame and the water surface from the upper window frame, as measured from the digital image. Based on this analysis, the water surface elevation at the moment was estimated as $6.865 \mathrm{~m}$ from the ground.

\subsubsection{Verification of results}

The colored dots depicted in Fig. 11a show the respective water surface levels ascertained from the photographic analysis described for Fig. 10 for four points located near the coast. They are shown with the same symbols in Fig. 11b. The colored solid lines represent the calculated time series of the water surface level at the location of $P 3$ (see Fig. 11b) for four cases among those presented in Table 2 . The $P 3$ located at the 

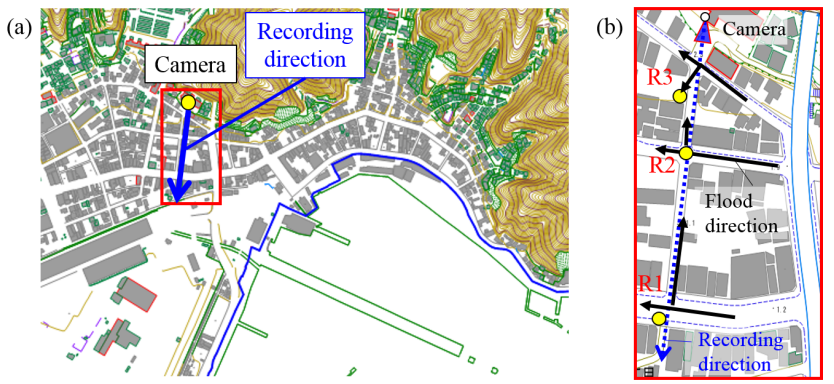

Figure 14. Location of video recording: (a) shooting direction and (b) crossings for measurement.

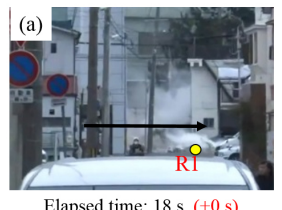

Elapsed time: $18 \mathrm{~s}(+0 \mathrm{~s})$

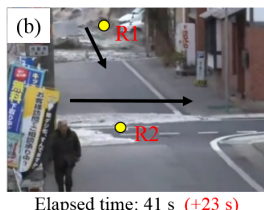

Elapsed time: $41 \mathrm{~s}(+23 \mathrm{~s})$

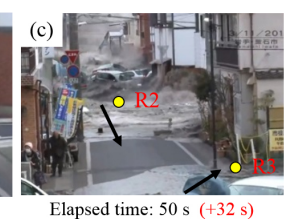

Figure 15. Images of wavefront passage at crossing.

center of the measurement area was selected for the plotting of the calculation results because the four points were mutually very close and calculation results were almost identical. All calculation results were mutually similar. They agreed fairly well with the observations. This outcome suggests that building wall permeability and assumptions of building arrays, with or without destroyed buildings, did not strongly influence the tsunami wave height near the coast.

The calculated highest water surface level was from T.P. $10.2 \mathrm{~m}$ (Case-3(a)) to $10.5 \mathrm{~m}$ (others) at around $2320 \mathrm{~s}$ after the first earthquake shock, although the actual measured highest water surface level was approximately T.P. $9.8 \mathrm{~m}$ at around $2222 \mathrm{~s}$ after the first shock. A possible reason for this difference is that the process of destruction of the breakwater at the bay mouth was ignored in tsunami propagation calculations for the ocean because the breakwater collapsed at an early stage of the tsunami event, but it is possible that the destruction of the breakwater dissipated the energy of intruding tsunami waves.

\subsection{Local highest water surface in the city}

\subsubsection{Field data source}

An academic joint research group was organized to conduct an extensive survey of the disaster caused by the 2011 Tohoku tsunami (TTJS Group, 2011; Mori et al., 2011). Their survey covered almost the entire Pacific coast damaged by the 2011 Tohoku tsunami, as marked by red in Fig. 2a. For the Kamaishi area, after estimation of the highest water surface level at several points from water surface traces remaining on poles, roofs, building walls, and the ground, they made

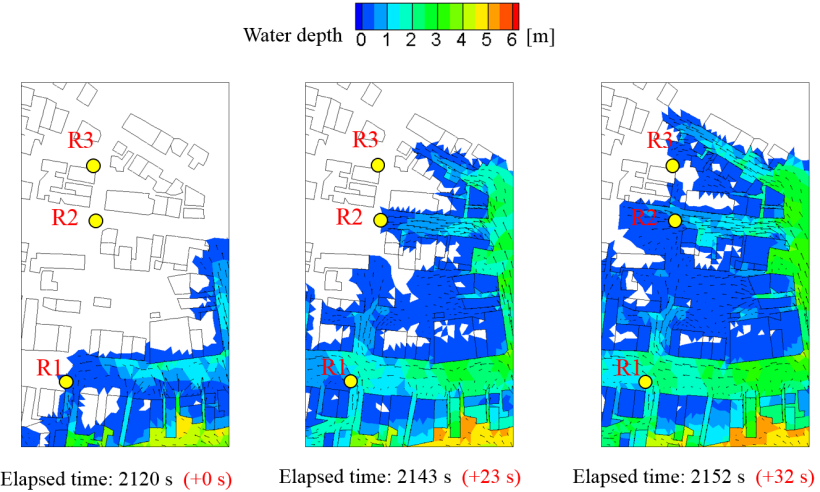

Figure 16. Calculated wavefront propagation corresponding to the measured values in Fig. 13.

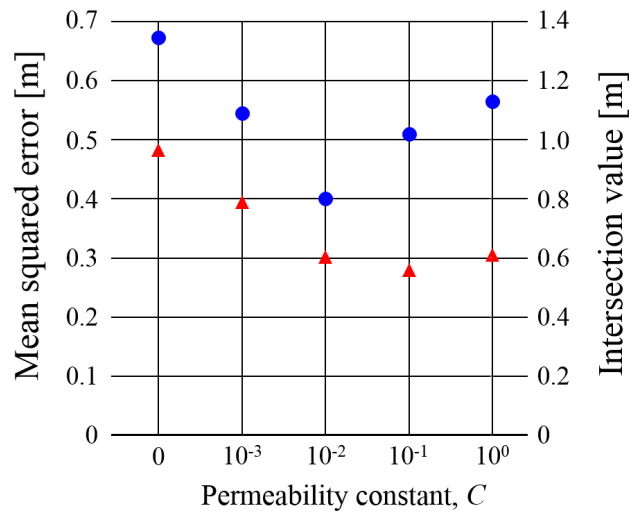

Figure 17. Degree of regression by $1: 1$ slope line: $\boldsymbol{\Lambda}$, mean squared error; $\bullet$, intersection value (difference from perfect agreement).

the dataset available to other research groups via the internet. We present those data on the map displayed in Fig. 12.

\subsubsection{Verification of results}

Figure 13 shows correlation between the measured and calculated highest water surface levels for four cases with symbols used in Fig. 12. Lines show perfect agreement (-- .), best fit regression line (-), and a regression line with $1: 1$ slope (-.) inserted in Fig. 13. In the cases of $C=0.0$ (Case1(a) and Case-1(b)), where water storage in buildings was not considered, large deviations are found in the western run-up data $(x)$ at the end of the inundation region, suggesting that the flow concentrated only on streets in the calculation led to overly efficient flood propagation.

Cases with $C=0.01$ (Case-3(a) and Case-3(b)) present results better than those obtained for the cases with $C=0.0$, which suggests that modification of the $\mathrm{BH}$ model by consideration of water storage in buildings might better fit Japanese wooden houses. Calculations for the building arrays after the tsunami impact (Case-(b) series) were less accurate than for those before tsunami impact (Case-(a) series), probably be- 
(a)

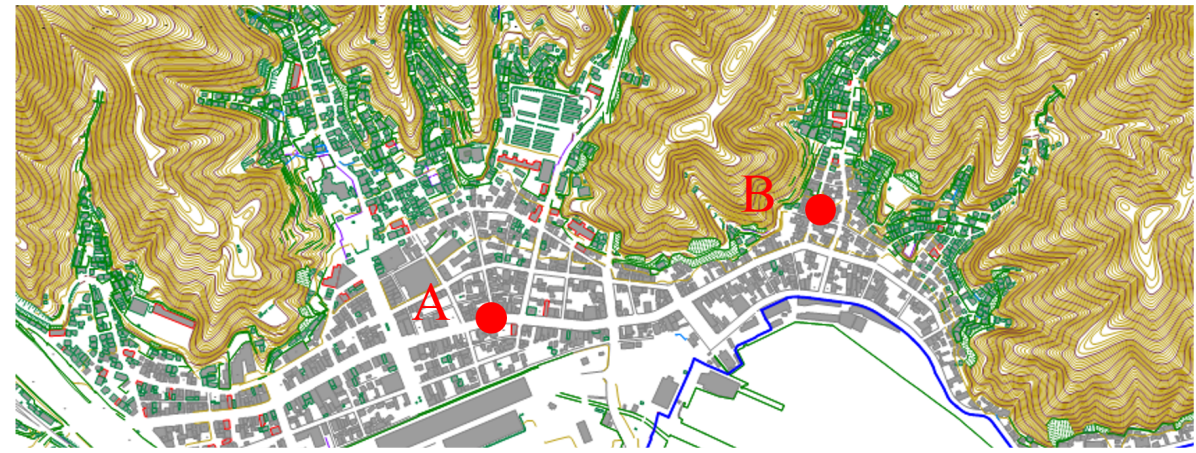

(b)

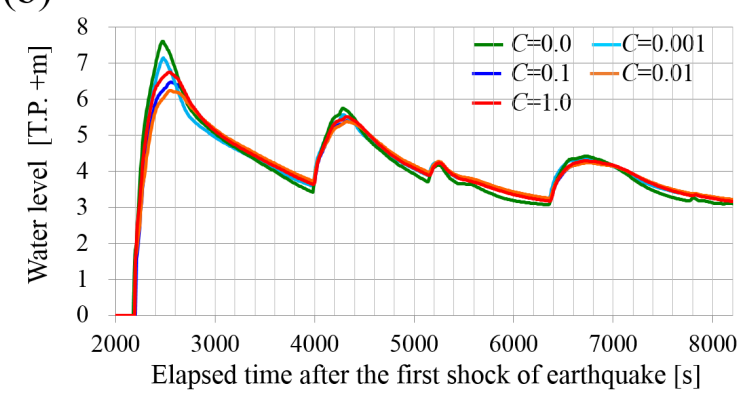

(c) ${ }_{8}$ Point A

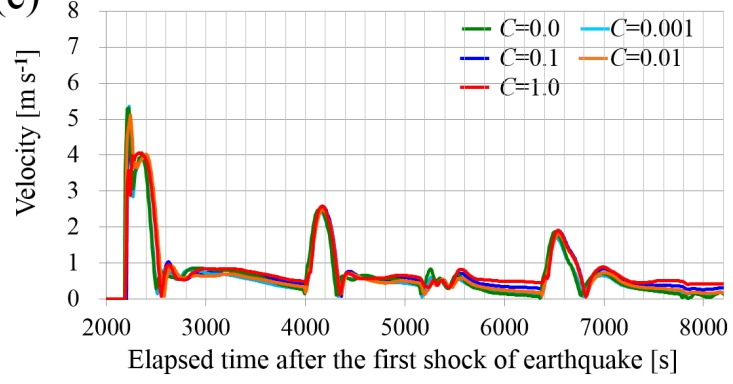

Point B

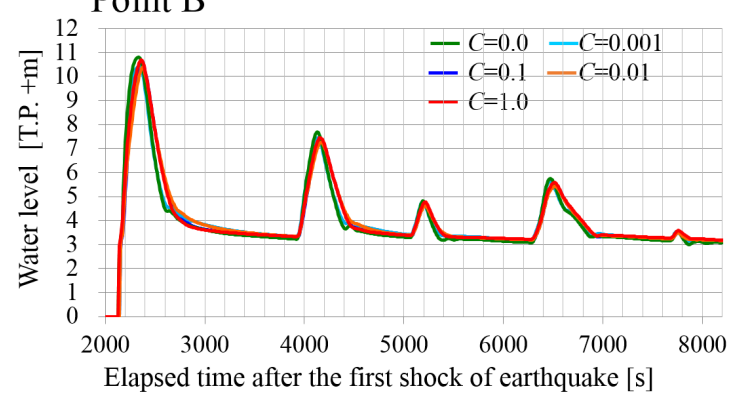

Point B

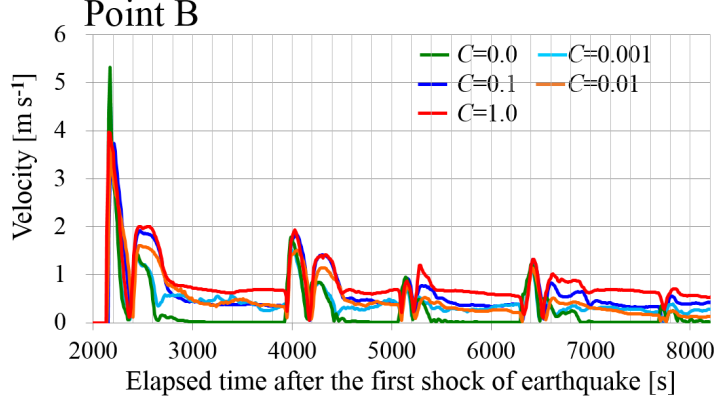

Figure 18. Time series of flow variables at the city center: (a) examination point, (b) water depth, and (c) flow velocity.

cause the highest water surface was generated during the first wave run-up, when houses had not been destroyed completely.

\subsection{Wavefront propagation on streets}

\subsubsection{Field data analysis}

A local resident recorded a video (YouTube, 2013) of tsunami waves from the point shown as the yellow dot in the direction indicated by the blue arrow presented in Fig. 14a. After we selected three images in which the tsunami front had just passed the street through three intersections $-R l$, $R 2$, and $R 3$ - marked by yellow dots in Fig. $14 \mathrm{~b}$, we ascertained time differences among the images, as shown in the bottom panels of Fig. 15a-c.

\subsubsection{Verification of results}

Figure 16 depicts snapshots of the inundation depth for Case3 (a) at the three moments when the calculated tsunami wavefront reached the three intersections denoted by $R 1, R 2$, and $R 3$ (see Fig. 14b), where the tsunami front passage was captured by a resident using a digital video camera. The red numbers below Fig. 16 represent the time passage between the tsunami front impacts. Comparison of the measured results shown at the bottom of Fig. 15 reveals that the calculated time differences agree well with the observed time differences.

\section{Discussion}

The reasonable value of $C$, unknown parameter in the model, is discussed in this chapter based on observed data presented in the previous chapter. Then, the tsunami effects on houses 
(a)

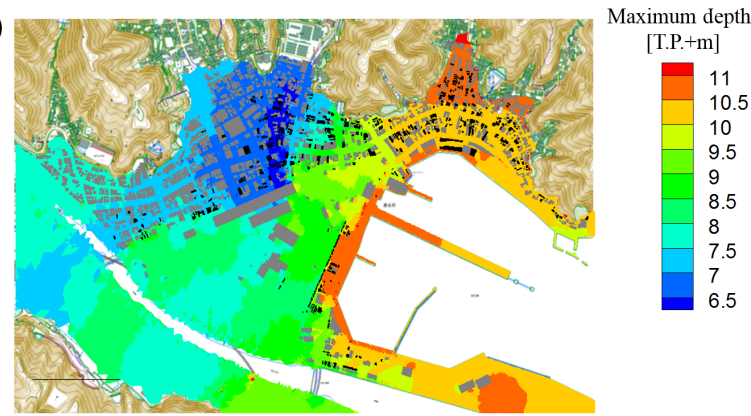

(b)

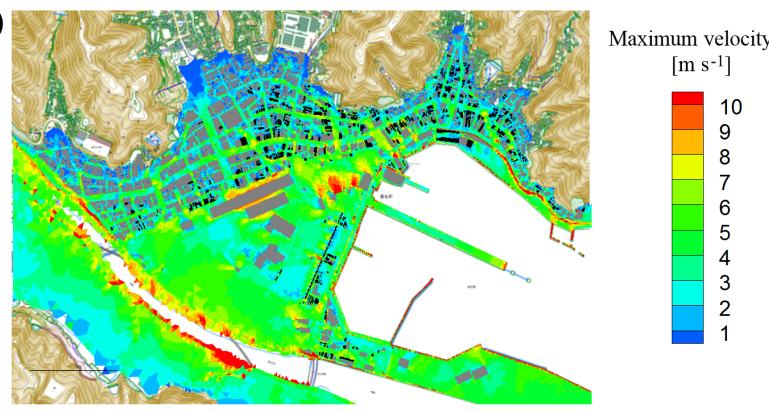

Figure 19. Mappings of maximum depth and maximum flow velocity during flooding (Case-3(a)): (a) maximum depth and (b) maximum velocity.

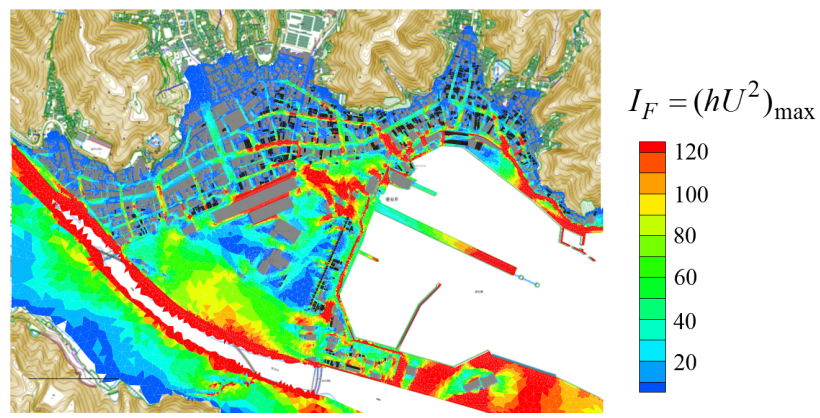

Figure 20. $I_{\mathrm{F}}$-value mapping for the original building array $(C=$ $0.01)$.

are estimated by introducing an indicator for tsunami run-up intensity. Furthermore, effects of rigid building arrays along the coast are tested numerically as a possible mitigation measure to reduce the hydraulic impact indicator in the city center.

\subsection{Permeability constant}

$C$ is a parameter representing the effects of water intrusion into buildings through openings during detention of the tsunami run-up flow. This is a distinctive point as well as a weak point of the present model because no physical evidence exists to assign a value to $C$ for each building: the actual value is expected to vary depending on the building
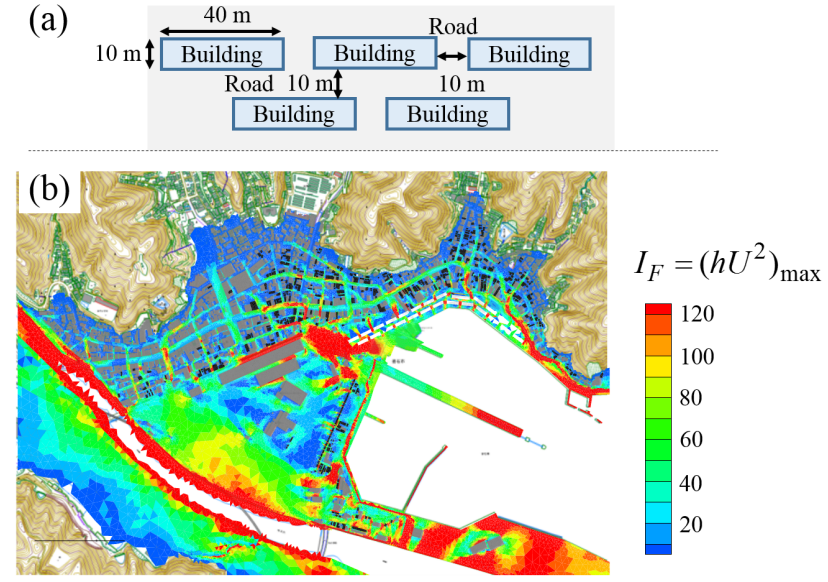

Figure 21. $I_{\mathrm{F}}$-value mapping for the testing building plot $(C=$ 0.01): (a) building plot and (b) $I_{\mathrm{F}}$-value mapping.

condition and stage of tsunami impact. However, it is also true that there must be some amount of water leakage through slits and cracks on the building side faces.

Figure 17 presents characteristics of data scattering around the regression lines of $1: 1$ slope for the Case-(a) series. The mean squared error $(\boldsymbol{\Lambda})$ became stable for $C>10^{-2}$ with the weak minimum at $C=10^{-1}$, whereas the intersection value of the regression line with $1: 1$ slope $(\bullet$, difference from the perfect agreement line) takes the minimum value of $0.8 \mathrm{~m}$ at $C=10^{-2}$. Considering that the error of the maximum wave height at the coastline was $0.4-0.7 \mathrm{~m}$ (see Fig. 11a), the result of Case-3(a) is apparently the best among the five cases.

Figure $18 \mathrm{~b}$ and $\mathrm{c}$ respectively shows the time series of water depth and flow velocity obtained using the five cases of the Case-(a) series at two points A and B in the city center, as shown in (a). Although the tsunami wave arrival time and peak values of depth and velocity depend on the value of $C$, the resultant sensitivity to $C$ does not appear to be excessive, considering ambiguous factors of other kinds in numerical simulations.

Although the discussion presented above might appear to be unclear and indefinite, the overall permeable constant $C=$ 0.01 for the building array before the tsunami arrival (Case3(a)) was adopted for the following discussion because the case provided the highest correlation with measured data.

\subsection{Tsunami effects on houses}

Figure 19 presents spatial distributions of the maximum inundation depth and the maximum flow velocity obtained from the Case-3(a) calculation, in which black rectangles represent houses destroyed by tsunami waves. The water depth was greater in the eastern part of the building collapse concentration area because the tsunami approached the city from the east, whereas higher flow velocities were found in 
western areas because the wavefront hitting at the end of the bay intruded directly into open spaces and the streets.

Considering that the forces on structures are proportional to the momentum flux, an indicator for tsunami run-up flow intensity, $I_{\mathrm{F}}$, was introduced as

$I_{\mathrm{F}}=\left(h U^{2}\right)_{\max }$,

where $h$ and $U$ respectively denote the inundation depth and flow velocity during the flood. Figure 20 presents a spatial distribution of $I_{\mathrm{F}}$, which is closely correlated with the distribution of collapsed houses colored black in the figure.

\subsection{Tsunami reduction effects of concrete buildings along the coast}

Construction of high embankments along the coast was stated as the primary countermeasure against tsunami run-up in reconstruction guidelines issued by the Japanese Government after the 2011 Tohoku tsunami (Cabinet Office, Government of Japan, 2011). However, such structures obstruct access to the sea, causing great inconvenience to cities with local communities that are mainly reliant on marine product industries. Some reports have suggested that large buildings protected the houses behind them from tsunami impact (e.g., Matsutomi et al., 2012; Takagi et al., 2014).

Therefore, the effects of building arrays along the coast on controlling the flood flow instead of a continuous seawall were tested numerically. White rectangles in Fig. 21 show the trial building plot: two building layers are lined alternately to prevent seawater from flowing straight to the city center, with daily traffic given access through a hook-shaped road system. The building footprint dimensions are presented above the figure.

The color contour in Fig. 21 shows the calculated $I_{\mathrm{F}^{-}}$ distribution. Compared with Fig. 20, the tsunami run-up flow intensity dropped drastically on streets where many wooden houses had been destroyed by the 2011 Tohoku tsunami. Results of this trial calculation suggest that properly arranged concrete buildings along the coast can function as a seawall, reducing damage to homes behind them and sheltering some evacuation routes, although special building equipment for emergencies must be provided on lower floors, such as rigid shutters that can be closed before tsunami wave impact, along with safety measures for lifeline services such as electrical power.

\section{Conclusions}

The approach presented in this paper demonstrated the possibility of accurate urban flood modeling with an internal hydraulic condition at building side faces, which allows water leakage into buildings, in the context of tsunami run-up in Kamaishi city caused by the 2011 Tohoku earthquake. When the wall permeable constant is set to zero, the model is equivalent to a BH model. A mesh system for calculation was generated using software (ANSYS ${ }^{\circledR}$ ICEM CFD $^{\mathrm{TM}}$ ) based on building footprints included in a digital map provided by GSI with a digital elevation model of $1.0 \mathrm{~m}$ resolution, which was also provided by GSI.

The permeable wall assumption is both the distinctive point and the weak point of the model because of the difficulty in assigning a realistic value of permeability to each building. In actuality, the value is expected to vary depending on the building condition and stage of tsunami impact. Moreover, it is true that some amount of water leakage occurs through openings, slits, and cracks on building side faces. In this study, five values of the permeability constant $C$ defined by Eq. (3) were examined from 0 (impermeable) through $10^{-3}, 10^{-2}, 10^{-1}$ to 1 . A comparison of computed results with field data suggests $C=10^{-2}$ overall for cases of tsunami flooding in Kamaishi city.

Examination of time series of water depth and flow velocity at the city center revealed that the consequent sensitivity on $C$ was not so great, except for a short duration around the first peak. Because accurate evaluation of hydraulic conditions at the first peak is important, further investigation is necessary to ascertain the $C$ value practically, based on results of field and experimental studies. However, considering that the original definition of the permeable constant was abstract and that the permeability model was a kind of perturbation from the building-hole model, further detailed consideration of the $C$ value might be meaningless at this point.

The purpose of modeling the tsunami run-up process is not only to predict hydraulic quantities such as inundation water depth but also to propose effective measures against tsunami disasters based on calculation results. This study adopted an indicator for run-up flow intensity: $I_{\mathrm{F}}=\left(h U^{2}\right)_{\max }$, where $h$ and $U$ respectively stand for the water depth and the flow velocity at each point during the flood. Results showed that the spatial mapping of the $I_{\mathrm{F}}$ value is correlated with the distribution of houses destroyed by the tsunami flow.

Numerical tests conducted for buildings along the coast demonstrated that two lines of alternately arranged concrete buildings can prevent seawater from flowing straight into the city center while maintaining daily traffic through a hookshaped road system. Therefore, the present model offers great potential as a tool to support the improvement of city layouts for enhanced safety against tsunami waves.

Data availability. The digital data of the building footprint are available at https://fgd.gsi.go.jp/download/menu.php (Geospatial Information Authority of Japan). The data of ground elevation are available at https://fgd.gsi.go.jp/download/menu.php (Geospatial Information Authority of Japan). The data of seafloor elevation are available at http://jdoss1.jodc.go.jp/vpage/depth500_file_j.html (Japan Oceanographic Data Center). The data of survey results are available at http://www.coastal.jp/tsunami2011 (the 2011 earthquake off the Pacific coast of Tohoku tsunami information). The 
video used for verification is available at http://www.youtube.com/ watch? $\mathrm{v}=\mathrm{aQj} 2 \mathrm{zn} 5 \mathrm{Axmk}$ (YouTube).

Competing interests. The authors declare that they have no conflict of interest.

Acknowledgements. We would like to thank the academic joint research group for their extensive survey of the 2011 tsunami disaster and for sharing the valuable data obtained in their survey. We also thank the River Division of the Department of Prefectural Land Development, Iwate Prefecture, for providing topographic data of the Kamaishi area for this study. Finally, we thank Prof. Takashi Nakamura of the Tokyo Institute of Technology for his assistance in compiling the program used for GPGPU (generalpurpose computing on graphics processing units) calculation.

Edited by: Mauricio Gonzalez

Reviewed by: two anonymous referees

\section{References}

Akoh, R., Hatakeyama, S., and Ishikawa, T.: Numerical Simulation of Tsunami Run-Up in Urban Area Taking into Account the City Layout, Proceedings of the 19th IAHR-APD Congress 2014, Hanoi, Vietnam, ISBN 978604821338-1, 2014.

Aronica, G. and Lanza, L. G.: Drainage efficiency in urban areas: a case study, Hydrol. Process., 19, 1105-1119, https://doi.org/10.1002/hyp.5648, 2005.

Aronica, G., Tucciarelli, T., and Nasello, C.: 2D multilevel model for flood wave propagation in flood-affected areas, J. Water Res. Plan. Man., 124, 210-217, https://doi.org/10.1061/(ASCE)07339496(1998)124:4(210), 1998.

Bricker, J. D., Gibson, S., Takagi, H., and Imamura, F.: On the need for larger Manning's roughness coefficients deepintegrated tsunami inundation models, Coast. Eng. J., 57, 155005, https://doi.org/10.1142/S0578563415500059, 2015.

Brown, J. D., Spencer, T., and Moeller, I.: Modeling storm surge flooding of an urban area with particular reference to modeling uncertainties: a case study of Canvey Island, UK, Water Resour. Res., 43, W06402, https://doi.org/10.1029/2005WR004597, 2007.

Brufau, P., Vázquez-Cendón, M. E., and García-Navarro, P. A.: Numerical model for the flooding and drying of irregular domains, Int. J. Numer. Meth. Fluids, 39, 247-275, 2002.

Bunya, S., Deitrich, J. C., Westerink, J. J., Ebersole, B. A., Smith, J. M., Atkinson, J. H., Jensen, R., Resio, D. T., Luettich, R. A., Dawson, C., Cardone, V. J., Cox, A. T., Powell, M. D., Westerink, H. J., and Roberts, H. J.: A high-resolution coupled riverine flow, tide, wind, wind wave, and storm surge model for southern Louisiana and Mississippi. Part I: Model development and validation, Mon. Weather Rev., 18, 345-377, 2010.

Cabinet Office, Government of Japan, Report of the Committee for Technical Investigation on Countermeasures for Earthquakes and Tsunamis Based on the Lessons Learned from the "2011 off the Pacific coast of Tohoku Earthquake", available at: http://www.bousai.go.jp/kaigirep/chousakai/tohokukyokun/pdf/ Report.pdf (last access: June 2017), 2011.

Central Disaster Prevention Council, Cabinet Office, Government of Japan, The tsunami fault model of 2011 off the Pacific coast of Tohoku Earthquake, available at: http://www.bousai.go.jp/jishin/ nankai/model/12/pdf/sub_1.pdf (last access: June 2017), 2012 (in Japanese).

Conde, D. A. S., Baptista, M. A. V., Sousa Oliveira, C., and Ferreira, R. M. L.: A shallow-flow model for the propagation of tsunamis over complex geometries and mobile beds, Nat. Hazards Earth Syst. Sci., 13, 2533-2542, https://doi.org/10.5194/nhess-132533-2013, 2013.

Gallegos, H. A., Schubert, J. E., and Sanders, B. F.: Two-dimensional, high-resolution modeling of urban dam-break flooding: a case study of Baldwin Hills, California, Adv. Water Resour., 32, 1323-1335, https://doi.org/10.1016/j.advwatres.2009.05.008, 2009.

Gallien, T. W., Schubert, J. E., and Sanders, B. F.: Predicting tidal flooding of urbanized embayments: a modeling framework and data requirements, Coast. Eng., 58, 567-577, https://doi.org/10.1016/j.coastaleng.2011.01.011, 2011.

Gayer, G., Leschka, S., Nöhren, I., Larsen, O., and Günther, H.: Tsunami inundation modelling based on detailed roughness maps of densely populated areas, Nat. Hazards Earth Syst. Sci., 10, 1679-1687, https://doi.org/10.5194/nhess-101679-2010, 2010.

Geospatial Information Authority of Japan (GSI): Observation of Crustal Movements by GPS Networks, Ministry of Land, Infrastructure, Transport and Tourism, available at: http://www.gsi. go.jp/chibankansi/chikakukansi40005.html (last access: January 2014) 2011 (in Japanese).

Geospatial Information Authority of Japan (GSI): The digital base map for reconstruction planning, available at: http://www.gsi.go. jp/kibanjoho/kibanjoho40022.html (last access: January 2014), 2011 (in Japanese).

Godunov, S. K.: A difference method for numerical calculation of discontinuous solutions of the equations of hydrodynamics, Math. USSR Sb+, 47, 271-306, 1959.

Guinot, V.: Multiple porosity shallow water models for macroscopic modeling of urban floods, Adv. Water Resour., 37, 40-72, https://doi.org/10.1016/j.advwatres.2011.11.002, 2012.

Honma, H.: Coefficient of flow volume on low overflow weir, Civil Engineering, Journal of Japan Society of Civil Engineers, 26, 635-645, 1940 (in Japanese).

Hunter, N. M., Bates, P. D. Neels, S., Pender, G., Villanueva, I., Wright, N. G., Liang, D., Falconer, R. A., Lin, B., Waller, S., Crossley, A. J., and Mason, D. C.: Benchmarking 2D hydraulic models for urban flood simulations, P. I. Civil Eng-Wat. M., 161, 13-30, https://doi.org/10.1680/wama.2008.161.1.13, 2008.

Imai, K., Imamura, F., and Iwama, S.: Advanced tsunami computation for urban regions, J. JSCE, Ser. B2 (Coast. Eng.), 69, I_311I_315, 2013 (in Japanese).

Imamura, F.: Simulation of wave-packet propagation along sloping beach by TUNAMI-code, in: Long-Wave Runup Models, edited by: Yeh, H., Liu, P. L. F., and Synolakis, C., World Scientific, ISBN 981-02-2909-7, 231-241, 1996.

Imamura, F., Yalciner, A. C., and Ozyurt, G.: TSUNAMI MODELLING MANUAL (TUNAMI model), International Research Institute of Disaster Science, Tohoku University, 
available at: http://www.tsunami.civil.tohoku.ac.jp/hokusai3/J/ projects/manual-ver3.1.pdf (last access: June 2017), 1995.

Japan Oceanographic Data Center: J-EGG500 (JODC-Export Grid data for Geographic - $500 \mathrm{~m}$ ), available at: http://www.jodc.go. jp/jodcweb/JDOSS/infoJEGG.html, last access: March 2011.

Kaiser, G., Scheele, L., Kortenhaus, A., Løvholt, F., Römer, H., and Leschka, S.: The influence of land cover roughness on the results of high resolution tsunami inundation modeling, Nat. Hazards Earth Syst. Sci., 11, 2521-2540, https://doi.org/10.5194/nhess11-2521-2011, 2011.

Komatsu, Y., Sasaki, J., and Matsumaru, R.: Hindcasting of 2004 Indian Ocean tsunami in Banda Aceh, Indonesia, using FVCOM, J. JSCE, Ser. B2 (Coast. Eng.), 66, 256-260, 2010.

Liang, D., Falconer, R. A., and Lin, B.: Coupling surface and subsurface flows in a depth averaged flood wave model, J. Hydrol., 337, 147-158, https://doi.org/10.1016/j.jhydrol.2007.01.045, 2007.

Liu, X., Sakai, S., Mikami, T., Iwama, S., Imamura, F., Shuto, N., and Kikuchi, H.: Numerical analysis of tsunami run-up and tsunami flood to a coastal city, Proceedings of the 28th International Conference Coastal Engineering 2002, Solving Coastal Conundrums, Cardiff, Wales, 1168-1175, 2002.

Matsutomi, H., Yamaguchi, E., Naoe, K., and Harada, K.: Damage conditions to reinforced concrete buildings and coastal black pine trees in the 2011 off Pacific Coast of Tohoku earthquake tsunami, J. JSCE, Ser. B2 (Coast. Eng.), 68, I_351-I_355, 2012 (in Japanese).

Mori, N., Takahashi, T., Yasuda, T., and Yanagisawa, H.: Survey of 2011 Tohoku earthquake tsunami inundation and run-up, Geophys. Res. Lett., 38, L00G14, https://doi.org/10.1029/2011GL049210, 2011.

Roe, P. J.: Approximate Riemann solvers, parameter vectors, and difference schemes, J. Comput. Phys., 43, 357-372, 1981.

Sanders, B. F., Schubert, J. E., and Gallegos, H. A.: Integral formulation of shallow-water equations with anisotropic porosity for urban flood modeling, J. Hydrol., 362, 19-38, https://doi.org/10.1016/j.jhydrol.2008.08.009, 2008.

Schubert, J. E. and Sanders, B. F.: Unstructured mesh generation and land cover based resistance for hydrodynamic modeling of urban flooding, Adv. Water Resour., 31, 1603-1621, 2008.

Schubert, J. E. and Sanders, B. F.: Building treatments for urban flood inundation models and implications for predictive skill and modeling efficiency, Adv. Water Resour., 41, 49-64, 2012.
Soares-Frazão, S., Lhomme, J., Guinot, V., and Zech, Y.: Two-dimensional shallow-water model with porosity for urban flood modelling, J. Hydraul. Res., 46, 45-62, https://doi.org/10.1080/00221686.2008.9521842, 2008.

Suppasri, A., Koshimura, S., and Imamura, F.: Developing tsunami fragility curves based on the satellite remote sensing and the numerical modeling of the 2004 Indian Ocean tsunami in Thailand, Nat. Hazards Earth Syst. Sci., 11, 173-189, https://doi.org/10.5194/nhess-11-173-2011, 2011.

Synolakis, C., Bernard, E., Titov, V. V., Kânoğlu, U., and Gonzalez, F.: Validation and verification of tsunami numerical models, Pure Appl. Geophys., 165, 2197-2228, https://doi.org/10.1007/s00024-004-0427-y, 2008.

Takagi, H. and Jeremy, D. B.: Assessment of the effectiveness of general breakwaters in reducing tsunami inundation in Ishinomaki, Coast. Eng. J., 56, 1450018, https://doi.org/10.1142/S0578563414500181, 2014.

Takahashi, S., Toda, K., Kikuchi, Y., Sugano, T., Kuriyama, Y., Yamazaki, H., Nagao, T., Shimosako, K., Negi, T., Sugeno, J., Tomita, T., Kawai, H., Nakagawa, Y., Nozu, A., Okamoto, O., Suzuki, K., Morikawa, Y., Arikawa, T., Iwanami, M., Mizutani, T., Kohama, E., Yamaji, T., Kumagai, K., Tatsumi, D., Washizaki, M., Izumiyama, T., Seki, K., Yeom, G., Takenobu, M., Kashima, H., Banno, M., Fukunaga, Y., Sakunaka, J., and Watanabe, Y.: Urgent Survey for 2011 Great East Japan Earthquake and Tsunami Disaster in Ports and Coasts, Technical note of the Port and Airport Research Institute, ISSN 1346-7840, No. 1231, April 2011 (in Japanese).

The 2011 Tohoku Earthquake Tsunami Joint Survey (TTJS) Group: http://www.coastal.jp/ttjt/, last access: 24 Jan 2013, 2011.

Titov, V. V. and Synolakis, C. E.: Modeling of breaking and nonbreaking log-wave evolution and runup using VTCS-2, J. Waterw. Port. C Div., 121, 308-316, 24, 1995.

Titov, V. V. and Synolakis, C. E.: Numerical modeling of tidal wave run-up, J. Waterw. Port. C Div., 124, 157-171, 1998.

Tomita, T., Yeom, G., Ayugai, M., and Niwa, T.: Effect of breakwaters on reducing flow depth during the Great East Japan Tsunami, Coastal Eng., 68, I_156-I_160, 2012.

YouTube, URL: http://www.youtube.com/watch?v=aQj2zn5Axmk, last access: June 2013.

Zhou, J. G., Causon, D. M., Mingham, C. G., and Ingram, D. M.: The surface gradient method for the treatment of source terms in the shallow-water equations, J. Comput. Phys., 168, 1-25, 2001. 